\title{
Implementasi Pendidikan Karakter Pada Matakuliah Matematika Sekolah Dasar Menggunakan Model CTL
}

\author{
Vivi Puspita ${ }^{1}$, Asrina Mulyati ${ }^{2}$, Didi Maielfi ${ }^{3}$ \\ 1,2,3 PGSD, STKIP Adzkia Padang, Sumatera Barat, Indoesia \\ vivipuspita.pendas@gmail.com
}

\begin{abstract}
Abstrak
Pendidikan karakter dilakukan secara berkesinambungan mulai dari sekolah dasar hingga pergutuan tinggi. Pendidikan karakter penting dimiliki oleh mahasiswa dalam memasuki duni kerja. Nilai nilai-nilai karakter tersebut seperti hormat dan peduli pada orang lain, tanggung jawab, jujur, memiliki integritas, dan disiplin. Penelitian ini bertujuan untuk menghasilkan suatu modul pembelajaran yang mengintekgrasikan pendidikan karakter. Penelitian yang dilakukan merupakan penelitian pengembangan (research and development) dengan menggunakan model 4D (four-D models) yang terdiri dari empat tahap. Keempat tahap itu adalah pendefinisian (define), perancangan (design), pengembangan (develop), dan penyebaran (disseminate). Pada artikel ini hanya membahas pada tahapan pendefinisian (define), dan perancangan (design). Instrumen pengumpulan data yang digunakan dalam penelitian ini adalah: Instrumen kevalidan, Instrumen kepraktisan, dan Instrumen keefektivan. Pengolahan data validitas modul menunjukan hasil valid sehingga modul dapat digunakan dalam perkuliahan.
\end{abstract}

Kata Kunci: Pendidikan karakter, Contextual Teaching and Learning, Modul

\begin{abstract}
Character education is carried out on an ongoing basis starting from elementary school to college. Important character education is owned by students in entering the world of work. The values of these characters such as respect and care for others, responsibility, honest, have integrity, and discipline. This study aims to produce a learning module that integrates character education. The research carried out is a research and development study using 4-D models (four-D models) consisting of four stages. The four stages are defining, designing, developing, and disseminating. In this article only discusses the stages of define, and design. Data collection instruments used in this study were: Validity instruments, practicality instruments, and effectiveness instruments. Data processing module validity shows valid results so the module can be used in lectures.
\end{abstract}

Keywords: character education, contextual teaching and learning, module

Masyarakat Ekonomi Asean (MEA) merupakan suatu kesepakatan antar negara Asean utuk mengatasi masalah-masalah ekonomi antar negara asean. Dengan perjanjian tersebut maka dilakukannya kesepakatan basar bebas dibidang pemodalan, barang dan jasa serta tenaga kerja. Terdapat dampak dari konsekuensi MEA, yakni dampak aliranan bebas barang bagi negara-negara ASEAN, danpak arus bebas jasa, danpak arus bebas investasi, dampak arus bebas modal dan dampak arus tenaga kerja.

Perguruan tinggi memiliki peranan penting dalam menghasilkan tenaga kerja yang mampu bersaing dalam MEA. Keberhasilan peserta didik di perguruan tinggi, tempat bekerja dan pada tatanan masyarakat tidak hanya ditentukan oleh kecerdasan otak semata. Goleman (2000:46) melalui penelitiannya mengatakan Iq hanya dapat memberikan sumbangan $20 \%$ terhadap kesuksesan sesorang, sedangkan $80 \%$ ditentukan oleh kecerdasan emosianoal. Kecerdasan emosional dinyatakan sebagai kemampuan merasakan, memahami, dan secara efektif menerapkan daya serta kepekaan informasi dari berbagai sumber berupa energy, informasi, kenoksi dan pengaruh yang manusiawi. Dengan demikian kecerdasan emosional memiliki kaitan yang erat dengan inisiatif, empati, motivasi, ketangguhan, 
optimism, dan kemampuan beradaptasi dengan lingkungan yang saat sekarang dinamakan dengan karakter.

Sebagai upaya peningkatan mutu pendidikan, maka kemenristek telah melakukan revolusi karakter bangsa melalui penatan kembali kurikulum pendididikan nasional Berdasarkan fungsi dan tujuan pendidikan nasional, jelas bahwa pendidikan di setiap jenjang, mulai pendidikan dasar hingga pendidikan tinggi, harus dirancang dan diselenggarakan secara sistematis guna mencapai tujuan tersebut. Dalam rangka pembentukan karakter peserta didik sehingga beragama, beretika, bermoral, dan sopan santun dalam berinteraksi dengan masyarakat, maka pendidikan harus dipersiapkan, dilaksanakan, dan dievaluasi dengan baik dan harus mengintegrasikan pendidikan karakter di dalamnya guna mewujudkan insan-insan Indonesia yang berkarakter mulia.

Pendidikan karakter seharusnya membawa peserta didik ke pengenalan nilai secara kognitif, penghayatan nilai secara afektif, dan akhirnya ke pengamalan nilai secara nyata. Inilah rancangan pendidikan karakter (moral) yang oleh Thomas Lickona disebut moral knowing, moral feeling, dan moral action (Lickona, 1991: 51). Karena itulah, semua mapel yang dipelajari oleh peserta didik di sekolah harus bermuatan pendidikan karakter yang bisa membawanya menjadi manusia yang berkarakter seperti yang ditegaskan oleh Lickona tersebut.

Melalui pendidikan karakter perguruan tinggi harus berpretensi untuk membawa peserta didik memiliki nilai-nilai karakter mulia seperti hormat dan peduli pada orang lain, tanggung jawab, jujur, memiliki integritas, dan disiplin. Di sisi lain pendidikan karakter juga harus mampu menjauhkan peserta didik dari sikap dan perilaku yang tercela dan dilarang. Pendidikan karakter tidak hanya mengajarkan mana yang benar dan mana yang salah kepada anak, tetapi lebih dari itu pendidikan karakter menanamkan kebiasaan (habituation) tentang yang baik sehingga peserta didik paham, mampu merasakan, dan mau melakukan yang baik.

Maraknya pendidikan karakter sebanding dengan munculnya berbagai permasalahan karakter di perguruan tinggi contoh seperti Detiknews.com (03 mei 2016) seorang mahasiswa membunuh dosennya dengan menikam korban. Kejadian ini bermula ketika tersangka dimarahi korban karena lupa membawa buku dan memakai kaos bukan kemeja saat bimbingan skripsi. Selanjutnya berita yang dilansir oleh sindonews.com (24 oktober 2014) guru sekolah dasar sering berkata kotor dan memukul siswa pada saat jam pelajaran. Permasalahan lain yaitu rendahnya disiplin dengan bolos kerja guru sekolah dasar, seperti berita yang dirilis oleh sorotpurworejo.com. Permasalahan di atas menunjukkan hilangnya budaya malu, tidak mampu berfikir logis dan kritis, kurangnya rasa kepedulian dan sikap ketangguhan dalam menyikapi suatu permasalahan, tanggung jawab serta disiplin. Tergerusnya/hilangnya nilai karakter baik dari segi peserta didik khususnya pendidikan di perguruan tinggi maupun lulusan yang dihasilkan oleh perguruan tinggi tersebut. Jika hal ini terus berkelanjutan maka Indonesia tidak akan mampu bersaing dengan negara-negara ASEAN, Pekerja/guru dari ASEAN akan masuk dan bekerja di Indonesia namun tenaga pengajar Indonesia tidak akan mampu bersaing dengan tenaga kerja luar negeri. 
Merespons sejumlah kelemahan dalam pelaksanaan pendidikan pendidikan karakter, terutama melalui mata kuliah Pendidikan Agama dan Pendidikan Kewarganegaraan, telah diupayakan inovasi pendidikan karakter yaitu Pendidikan karakter dilakukan secara terintegrasi ke dalam semua mata kuliah Integrasi yang dimaksud meliputi pemuatan nilai-nilai ke dalam substansi pada semua mata kuliah dan pelaksanaan kegiatan perkuliah termasuk mata kuliah matematika. Pada tahap ini dosen diminta untuk mampu mengaitkan konsep-konsep pendidikan karakter pada mata kuliah matematika. Menurut Soekidjo, dkk (2013) pelaksanaan pengembangan karakter yang diintegrasikan dalam pembelajaran mendapatkan respon yang memuaskan dan mampu mengeksplorasi nilai-nilai karakter seperti rela berkorban, disiplin, penegakan aturan, kesadaran, ketertiban, disiplin, jujur dan disiplin.

Dengan menggunakan pendekatan CTL dalam modul mata kuliah pembelajaran matematika SD. CTL dapat mendorong siswa untuk lebih mengembangkan, memperbanyak kesiapan, serta penguasaan keterampilan dalam proses kognitif pengenalan siswa. Langkah CTL yang melibatkan aktivitas mental menimbulkan pengetahuan yang bersifat sangat pribadi/individual sehingga dapat kokoh/mendalam tertinggal dalam jiwa siswa. Kegiatan tersebut juga dipercaya untuk mampu memberikan kesempatan kepada siswa untuk berkembang dan maju sesuai dengan kemampuannya masing-masing, Mampu mengarahkan cara siswa belajar, sehingga lebih memiliki motivasi yang kuat untuk belajar giat. Selanjutnya dapat Membantu siswa untuk memperkuat dan menambah kepercayaan pada diri sendiri dengan proses penemuan sendiri

Berdasarkan penjelasan di atas jelaslah bahwa CTL tidak hanya membantu siswa dalam menguasai materi pembelajaran melalui proses penemuan. Namun juga memfasilitasi guru dalam menanamkan karakter kepada siswa. Asumsinya adalah melalui kegiatan penemuan akan menimbulkan karakter yang membuat siswa memiliki integritas, jujur, dan loyal. Melalui kegiatan CTL siswa juga dapat membentuk pola pikir terbuka serta tidak suka memanfaatkan orang lain. Melalui interaksi dalam CTL akan dapat membentuk karakter atau sikap peduli dan perhatian terhadap orang lain maupun kondisi sosial lingkungan sekitar sehingga siswaakan dapat menghargai dan menghormati orang lain. Pembelajaran dengan CTL membutuhkan pola pikir yang sistematis, kritis dan analitis akan menunjang pembentukan rasa bertanggung jawab, disiplin, dan selalu melakukan sesuatu dengan sebaik mungkin.

\section{METODE}

\section{Model Pengembangan}

Penelitian ini merupakan penelitian pengembangan (research and development) dengan menggunakan model 4-D (four-D models) yang terdiri dari empat tahap. Menurut Thiagarajan dalam Trianto (2011:189) keempat tahap itu adalah pendefinisian (define), perancangan (design), pengembangan (develop), dan penyebaran (disseminate).

\section{Prosedur Pengembangan}

Tahap Pendefinisian (define) 
Tahap pendefinisian bertujuan untuk menentukan masalah dasar yang dibutuhkan dalam pengembangan modul mata kuliah pembelajaran matematika di sekolah dasar sehingga dapat menjadi alternatif bahan ajar yang digunakan di perguruan tinggi. Adapun langkah-langkah kegiatan dalam tahap define yaitu analisis kurikulum, analisis silabus, analisis literatur dan analisis konsep.

Tahap Perancangan (design)

Tahap design bertujuan untuk merancang modul yang terintegrasi pendidikan karakter pada mata kuliah pembelajaran di skeolah dasar berbasis CTL yang sesuai dengan analisi pendahuluan atau kebutuhan. Perancangan modul disesuaikan dengan ketentuan perguruan tinggi Perancangan modul memperhatikan aspek didaktik, isi, bahasa dan penyajian.

Tahap pengembangan (develop)

Setelah modul selesai dirancang kemudian dilakukan uji validitas, praktikalitas dan efektivitas terbatas. Tahap ini bertujuan untuk menghasilkan produk yang sudah valid, praktis, dan efektif. Langkah-langkah pengembangannya adalah sebagai berikut:

Prosedur pengembangan di atas dapat di gamarkan sebagai berikut

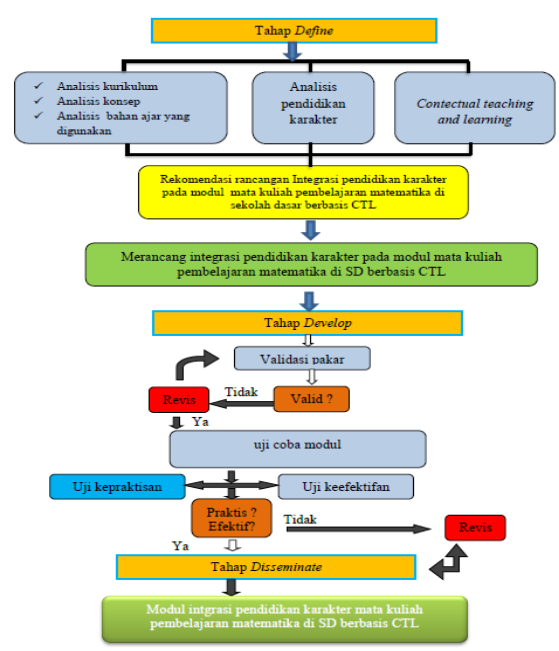

\section{Gambar 2. Diagram Prosedur Pengembangan modul}

Jenis data pada penelitian ini adalah data primer, yaitu data yang diambil dari hasil validasi mosul yang dilakukan oleh validator. Data yang diperoleh pada pelaksanaan uji coba berupa: (1) hasil pengamatan penggunaan modul perkuliahan, (2) hasil pengamatan aktivitas mahasiswa dari observer, (3) data angket respon mahasiswa terhadap modul perkuliahan yang diujicobakan, (4) data angket respon dosen terhadap modul perkuliahan yang diujicobakan, dan (5) data penilaian karakter. Instrumen pengumpulan data yang digunakan dalam penelitian ini adalah: Instrumen kevalidan, Instrumen kepraktisan, dan Instrumen keefektivan. 


\section{HASIL}

Pengembangan modul terintegrasi pendidikan karakter berbasis CTL dengan menggunakan model 4-D memiliki hasil sebagai berikut. Tahap Pendefinisian. Pada tahap ini dilakukan analisis kurikulum, analisis karakter siswa, analisis literatur dan analisis konsep. Hasil analisis konsep menunjukkan bahwa proses perkuliahan yang dilakukan dominan teacher senter dengan cara transfer pengetahuan. Proses pembelajaran belum mengimplementasikan pendidikan karakter. Selanjutnya modul beriskan uraian materi kegiatan yang harus dihafalkan mahasiswa sehingga belum memungkinkan terlaksananya pengkontruksian pengetahuan secara mandiri. Subjek uji coba pada penelitian adalah usia dewasa 17-19 tahun. Untuk mempelajari karakteristik tersebut dilakukan pengamatan pada saat perkuliahan. Hasil pengamatan menunjukkan bahwa mahasiswa mudah lupa terhadap materi yang telah dipelajarinya. Hal ini disebabkan karena tidak terlibat dalam proses membangun pemahaman, perkuliahan cenderung dilakukan dengan cara mendengar dan memperhatikan dosen menyampaikan materi di depan kelas.

\section{Tahap Perencanaan}

Hasil tahap pendefinisian dijadikan dasar pada tahap perancangan. Setelah indikator pembelajaran dirumuskan, serta konsep utama ditetapkan maka langkah selanjutnya adalah merancang modul perkulihan pembelajaran matematika SD. Berikut ini akan diuraikan karakteristik modul yang telah dikembangkan

\section{Cover}

Cover memuat identitas/ judul Modul mata kulian pembelaaran matematika SD. Selain itu, pada cover juga terdapat LOGO STKIP Adzkia, Foto Mahasiswa sedang melakukan diskusi yang mencerminkan karakter cerdas dan bernuansa islami. Warna background utama yang digunakan pada modul adalah putih, warna biru dan merah dipilih berdasarkan warna penciri institusi, serta secara filosofinya warna biru menggambarkan kenyamanan sedangkan warna merah melambangkan keberanian, berani dalam hal menerima tantangan termasuk dalam hal memecahkan masalah kontekstual dalam perkuliahan.

\section{Kata Pengantar}

Kata pengantar berisi tentang ucapan syukur dan tujuan penulis merancang LKS terintegrasi pendidan karakter. Kata pengantar dibuat dengan kata-kata yang mudah dipahami. Judul kata pengantar menggunakan huruf camria math ukuran 13 dan kata-kata di dalam kata pengantar menggunakan huruf yang sama dengan ukuran 12.

\section{Daftar isi}

Daftar isi berisikan halaman yang menuntun siswa atau guru ke materi atau lembar yang diinginkan. Jenis tulisan Comic sans MS ukuran 12..

\section{Halaman judul tiap Bab}

Halaman judul pada tiap bab di tulis dalam bentuk persegi sehingga memfokusman peserta didika menemukan bagian yang akan di pelajari. Judul di tulis dengan huruf capital dengan jenis Cambria 
Math ukuran 26. Selajutnya disertai dengan pendahuluan. Pendahuluan menjabarkan tentang gambaran materi yang akan dipelajari serta hubungannya dengan konteks kehidupan nyata. Pada pendahuluan dipaparkan topik pembelajaran yang mempu mengembangkan rasa keingintahuan peserta didik.

\section{Soal latihan}

Modul ini juga dilengkapi dengan soal-soal latihan yang harus dikerjakan peserta didik setelah melakukan perkuliahan . Pengerjaan soal latihan dapat meningkatkan pemahaman peserta didik. Jumlah soal yang ada pada setiap $\mathrm{BAB}$ / SUBBAB adalah 10 buah soal yang terdiri dari soal pemahaman dan aplikasi dari konsep yang telah dipelajari. Berikut merupakan contoh soal latihan yang terdapat pada modul

\section{Daftar Rujukan}

Di akhir bab dituliskan buku sumber yang dapat digunakan oleh peserta didik dalam menambah pengetahuannya terhadap topik pembelajaran

\section{Tahap Pengembangan}

Tahap pengembangan bertujuan untuk menghasilkan modul Pembelajaran matematika Sekolah dasar terintegrasi pendidikan karakter dengan menggunakan pendekatan CTL yang valid, praktis dan efektif. Tahap pengembangan yang dimaksud meliputi:

\section{Validasi Perangkat Pembelajaran}

Uji validitas modul Pembelajaran matematika Sekolah dasar terintegrasi pendidikan karakter dengan menggunakan pendekatan CTL dilakukan oleh 3 orang dosen Dosen yang menjadi validator berasal dari 2 bidang kahlian yaitu matematika dan bahasa. Berikut diuraikan hasil validasi modul. Berikut merupakan hasil validasi untuk aspek kelayakan isi

\section{Tabel 1.}

Hasil Validasi Modul Aspek kelayakan Isi

\begin{tabular}{lcc}
\hline \multicolumn{1}{c}{ Indikator Penilaian } & Rata-rata & Kategori \\
\hline $\begin{array}{l}\text { A. Kesesuaian materi dengan capaian } \\
\text { pemelajaran }\end{array}$ & 2.8 & Valid \\
\hline B. Keakuratan Materi & 2.71 & Valid \\
\hline C. Pendukung Materi Pembelajaran & 2.53 & Valid \\
\hline D. Kemutakhiran Materi & 2.83 & Valid \\
\hline \multicolumn{1}{c}{ rata-rata } & 2.72 & Valid \\
\hline
\end{tabular}

Hasil analisis pada Tabel 1 menunjukkan bahwa untuk nilai setiap indikator pada aspek kelayakan isi berkisar dari 2.5 hingga 3 dengan kategori valid. Secara umum validitas modul aspek isi adalah 2.72 dengan kategori sangat valid. Hasil validasi menggambarkan bahwa modul sudah sesuai dengan capaian pembeajaran yang ingin dicapai. Keakuratan materi, materi pendukung serta keterbaruan materi telah dirancang dengan valid..

Aspek lain yang dilihat dalam penilaian modul Pembelajaran matematika Sekolah dasar terintegrasi pendidikan karakter dengan menggunakan pendekatan CTL adalah aspek penyajian. Berikut merupakan hasil validasi modul untuk aspek penyajian. 


\section{Tabel 2.}

Hasil Validasi modul untuk Aspek Penyajian

\begin{tabular}{llcc}
\hline No & \multicolumn{1}{c}{ Aspek } & Rata-rata & Kategori \\
\hline 1 & Teknik Penyajian & 2.7 & Valid \\
\hline 2 & Pendukung Penyajian & 2.8 & Valid \\
\hline 3 & Penyajian Pembelajaran & 3 & Valid \\
\hline 4 & Kelengkapan Penyajian & 3 & Valid \\
\hline & Rata-rata & 2.9 & Valid \\
\hline
\end{tabular}

Hasil analisis yang disajikan pada Tabel 2 menggambarkan bahwa nilai rata-rata setiap indikator pada aspek penyajian berkisar dari 2.7 hingga 3 dengan kategori valid. Secara umum validitas modul dari aspek penyajian adalah 2.9 dengan kategori valid. Dengan demikian pada aspek penyajian dinyatakan valid.

Aspek lain yang dilihat dalam penilaian modul Pembelajaran matematika Sekolah dasar terintegrasi pendidikan karakter dengan menggunakan pendekatan CTL adalah penggunaan Bahasa. Hasil validasi modul dari aspek bahasa dapat dilihat pada Tabel 3 berikut.

\section{Tabel 3.}

\section{Hasil Validasi Modul untuk Aspek Bahasa}

\begin{tabular}{|llcc|}
\hline No & \multicolumn{1}{c}{ Aspek Bahasa } & Rata-rata & Kategori \\
\hline 1. & Lugas & 3 & Valid \\
\hline 2. & Komunikatif & 2.8 & Valid \\
\hline 3. & Dialogis dan interaktif & 3.3 & Valid \\
\hline 4 & Keruntutan dan keterpaduan alur pikir & 2.5 & Valid \\
\hline 5 & Penggunaan istilah, simbol, atau ikon & 2.8 & Valid \\
\hline \multicolumn{2}{r}{ Rata-rata } & 2.88 & Valid \\
\hline
\end{tabular}

Hasil analisis pada Tabel 3 menggambarkan bahwa nilai rata-rata setiap indikator adalah 2.88 dengan kategori valid. Secara umum validitas modul dari aspek bahasa adalah 2.88 dengan kategori valid. Hasil validasi menggambarkan bahwa penggunaan kalimat pada LKS telah sesuai dengan kaidah bahasa Indonesia yang baik. Kalimat yang digunakan telah runtut dan sesuai dengan alur berfikir. Bahasa juga disampaikan dengan lugas, komunikatid dan interaktif serta dengan penggunaan istilah, simbol dan ikon yang mumdahkan peserta didik. Dengan demikian modul dinyatakan valid dalam aspek bahasa.

Aspek terakhir yang divalidasi adalah aspek penyajian pengintegrasian pendekatan CTL dan pendidikan karakter, Berikut merupakan hasil validasi modul dari aspek pengintegrasian pendekatan CTL dan pendidikan karakter.

\section{Tabel 4.}

Hasil Validasi modul aspek pengintegrasian pendekatan CTL dan pendidikan karakter

\begin{tabular}{|llcc|}
\hline No & \multicolumn{1}{c}{ Aspek Penyajian } & Rata-rata & Kategori \\
\hline 1. & Kontekstual & 3 & Valid \\
\hline 2. & masyarakat belajar & 2.7 & Valid \\
\hline \multicolumn{2}{r}{ Rata-rata } & 2.85 & Valid \\
\hline
\end{tabular}


Berdasarkan hasil validasi pada Tabel 4 terlihat bahwa nilai rata-rata setiap indikator aspek pengintegrasian pendekatan CTL dan pendidikan karakter adalah 2.85. Secara umum validitas LKS dari aspek pengintegrasian pendekatan CTL dan pendidikan karakter 2.85 dengan kategori valid. Jadi, dapat disimpulkan bahwa modul telah dinyatakan valid pada aspek pengintegrasian pendekatan CTL dan pendidikan karakter.

Secara keseluruhan validitas dari LKS dapat dilihat pada tabel 5 berikut.

\section{Tabel 6.}

Hasil Validasi LKS secara Keseluruhan

\begin{tabular}{|llcc|}
\hline No & \multicolumn{1}{c|}{ Aspek } & Rata-rata & Kategori \\
\hline 1. & Isi & 2.72 & Valid \\
\hline 2. & penyajian & 2.9 & Valid \\
\hline 3. & Bahasa & 2.88 & Valid \\
\hline 4. & $\begin{array}{l}\text { pengintegraisan pendekatan CTL } \\
\text { dan pendidikan karakter }\end{array}$ & 2.85 & Valid \\
\hline \multicolumn{2}{|c|}{ Rata-rata } & 2.84 & Valid \\
\hline
\end{tabular}

Hasil validasi pada Tabel 6 menggambarkan bahwa rata-rata uji validitas modul pada aspek isi, penyajian, bahasa dan pengintegrasian CTL dan pendidikan keseluruhan adalah 2,84 dengan kategori valid. Ini membuktikan bahwa modul telah disusun berdasarkan prinsip-prinsip, kategogi, langkah yang sesuai dengan taraf berfikir mahasiswa. Proses pembelajaran dirancang dengan mengaktifkan kemampuan siswa dalam mengkontruksi pengetahuan dengan pembelajaran contekstual teaching and learning. Melalui kegiatan pembelajaran CTL guru dapat mengembangkan nilai-nilai karakter seperti jujur, demokrasi, bertanggungjawab, mandiri, disiplin, kerjakeras, kreatif, rasa ingin tau dan sebagainya Maryanti dan Pratna (2017). Sistem pembelajaran mengedepankan interaksi sosial antar sesma mahasisw amaupun siswa dengan guru sehingga berdampak pada karakter tanggung jawab, adil Jadi, dapat disimpulkan bahwa modul Pembelajaran matematika Sekolah dasar terintegrasi pendidikan karakter dengan menggunakan pendekatan CTL telah valid. Modul berkualitas tinggi memenuhi aspek validasi yang terdiri dari relevansi dan konsistensi. Kriteria perangkap sesuai dengan prinsip pengetahuan ilmiah serta di kembangkan secara logis, Nieveen (2007)

\section{KESIMPULAN}

Berdasarkan hasil penelitian maka Modul pembelajaran matematika sekolah SD telah dinyatkan valid dari aspek isi yaitu kesesuai materi dengan capaian pembelajaran, keakuratan materi, pendukung materi pembelajaran dan kemutakhiran materi,selanjutnya valid pada aspek bahasa mencakup penggunaan bahasa yang lugas, komumikatif, dialogis dan interaktif, keruntutan dan keterpaduan alur pikir, pnggunaan istilah, simbol dan okon. Aspek terakhir adalah valid pada kriteria penerpan model Model CTL yaitu memuat aspek masalah kontekstual serta pengorganisasisan kegiatan masyarakat belajar. 


\section{DAFTAR PUSTAKA}

Andi Prastowo. 2012. Panduan Membuat Bahan Ajar Inovatif. Jakarta: Diva Press.

Arikunto, S. 2008. Dasar-dasar Evaluasi Pendidikan. Jakarta: Bumi Aksara.

Cepi Riyana \& Rudi Susilana. 2008. Media Pembelajaran: Hakikat, Pengembangan, Pemanfaatan dan Penilaian. Bandung: Wacana Prima.

Depdiknas. 2008. Kamus besar Bahasa Indonesia Pusat Bahasa. Jakarta: Gramedia Pustaka.

Depdiknas. 2008. Pengembangan Sistem Manajemen dan Kepemimpinan Sekolah Menengah Kejuruan. Jakarta: Departemen Pendidikan Nasional. Direktorat Pembinaan Sekolah Menengah Kejuruan.

Doni Koesoema, A. 2007. Pendidikan Karakter, Strategi Mendidik Anak di Zaman Global. Jakarta: Grasindo.

Echols \& Shadily. 1995. An Indonesian-English Dictionary. Cornell University Press.

Gerson, Richard. F. 2004.Mengukur Kepuasan Pelanggan, PPM, Jakarta.

Golemen, Daniel. 2005. Working With Emotional Intelligence. (Terjemahan Alex Tri Kancono Widodo), PT Gramedia : Jakarta.

Jefris Santama. Mahasiswa UMSU Buntuti Dosennya ke Kamar Mandi Sebelum Membunuh. http//:www.detiknews.com (03 Mei 2016)

Kemdiknas. 2010. Pengembangan Pendidikan Budaya dan Karakter Bangsa. Jakarta: Puskur-Balitbang. Kemdiknas.

Lickona, T. Educating for character: How our schools can teach respect and responsibility. New York: Bantam Books, 1991

Maryanti iyan, pratna nanang. 20017 Integrasi nilai-nilai karakter matematika melalui pembelajaran kontekstual.https://journal.institutpendidikan.ac.id/index.php/mosharafa/article/view/mv6n3 3/ $\underline{326}$

Muhammad Moeslim. Guru SDN Aniaya Siswa. http//:www.sindonews.com (24 Oktober 2014). Muliyardi. 2006. Pengembangan Model Pembelajaran Matematika Menggunakan Komik di Kelas 1 $S D$. Disertasi UNESA Surabaya. Tidak Diterbitkan.

Nieveen, N. 1999. Prototyping to Reach Product Quality. In J. van den Akker, R.M.Branch, K. Gustafson, N. Nieveen, \& T. Plomp (Eds), Design Approaches And Tools In Education And Training. Boston: Kluwer Academic, 125-136.

Riduan. 2009. Dasar-Dasar Statistika. Bandung: Alfabeta.

Trianto. 2011. Mendesain Model Pembelajaran Inovatif-Progresif, Jakarta: Kencana Prenada Media Group 